\title{
NATURAL RESOURCES IN NORTH EAST REGION OF INDIA
}

\author{
L.C. DE \& D.R. SINGH
}

ICAR-NRC for Orchids, Pakyong-737106, Sikkim

\begin{abstract}
The North East India comprising of eight states, namely Assam, Arunachal Pradesh, Meghalaya, Manipur, Mizoram, Nagaland, Sikkim and Tripura have a total geographical area of $262180 \mathrm{~km}^{2}$ and is characterized by fragility, marginality, inaccessibility, cultural heterogeneity, ethnicity and rich in biodiversity. The traditional agricultural systems in the region have low cropping intensity, subsistence farming, undulating topography and faulty land use pattern. The prospects of the region include mega biodiversity hot spot areas and abundant natural resources such as land and soils, minerals, industrial resources like oils, forest covers, agricultural land, rivers, indigenous crop germplasms, flowers and ornamental plants, medicinal and aromatic plants, livestock, poultry and fisheries. Prevalence of diverse agro-climatic conditions and natural vegetations have become a niche of a number of native germplasms of cereals, grain legumes, oil seeds, tuber crops, fruits, vegetables, spices, medicinal and aromatic plants and indigenous farming systems for sustenance of rural population.
\end{abstract}

KEYWORDS: Northeast States, Natural Resources, Biodiversity \& Germplasm

Received: Aug 07, 2017; Accepted: Aug 24, 2017; Published: Aug 28, 2017; Paper Id.: IJASROCT20178

\section{INTRODUCTION}

The North East India covers eight states, namely Assam, Arunachal Pradesh, Meghalaya, Manipur, Mizoram, Nagaland, Sikkim and Tripura has a total geographical area of $262180 \mathrm{~km} 2$, which is about 8 per cent of the country's total area with a population of about 40million. The Net sown area is higher in Assam (34.12per cent) where plains account for84. 44per cent of its total geographical area followed by Tripura (23.48per cent) while Arunachal Pradesh has a lowest net sown area (2.06per cent). The cropping intensity is highest in Tripura (160per cent) followed by Manipur (152per cent). About 1.67 million ha area is under shifting cultivation (jhum cultivation) Out of 4 million ha net sown area of the region about 1.3 million ha suffer serious soil conservation problems.

Land is a critical resource in many of the NE states. The region's agricultural system is predominantly traditional. The overall geographical land to man ratio for the NE region ( 0.67 hectare / person) is much higher than the national average ( 0.32 hectare/person). Population to land ratio is highest in Arunachal Pradesh followed by Mizoram, Sikkim and Manipur.

The per cent utilization of cultivable area in the NE regions (62.04\%) less than the national average (73.05\%). About $80 \%$ of the farmers in the NE region belong to small (less than 1.44ha) and marginal (less than 0.40 ha) category. Moreover, with the increase in population, the average size of land holding is gradually reduced over the years. This is primarily because the hilly terrain constitutes nearly two third of the regions, geographical area, and large sized holding are not feasible. The average size of land holding for the NE States (1.60 ha) is marginally higher than the all India (1.57 ha). Among the NE States the average size of land holding is highest in Nagaland (6.92 ha) and 
lowest in Tripura (0.97ha).

The region receives an annual average rainfall of $2000 \mathrm{~mm}$ accounting for about 10percent of the country's total precipitation. The soil of the region is acidic to strongly acidic in nature accounting 70 percent of the total geographical area Low soil $\mathrm{pH}$ is basically due to leaching of the bases under the influence of heavy precipitation. Soils are rich in organic matter. Forest cover in the region is 14.2 million ha which is about 54.16per cent of total geographical area, even higher than the national average (19.39 per cent). Mostly, the region is characterized by fragility, marginality, inaccessibility, cultural heterogeneity, ethnicity and rich in biodiversity. About 82per cent population depends on agriculture and allied sector for livelihood in the absence of industries, except in the state of Assam. Around56per cent of the area is under low altitude, 33per cent mid altitude and 11per cent under high altitude. The agricultural production system is characterized by and large CDR (Complex, diverse risk prone) type, low cropping intensity, subsistence farming, undulating topography and faulty land use pattern with an annual loss of soil of $46 \mathrm{t} / \mathrm{ha}$. Fertilizer consumption in the region is only about $12 \mathrm{~kg} / \mathrm{ha}$ and chemical pesticides use is very meagre $(0.14 \mathrm{~g} / \mathrm{ha})$. Only $0.88 \mathrm{mhm}$ water is used out of $42.5 \mathrm{mhm}$ and rest is lost as run-off. Judicious utilization and conservation of natural resources is the approach in the farming system concurrent policy and research back up to increase production, add value to the produce and market management.

\section{Prospects of the Region}

- One of the 12-mega biodiversity hot spot areas

- Abundant natural resources

- $\quad$ Geographical area-- 26.45 (million ha)

- $\quad$ Forest --17.11 (million ha)

- $\quad$ Agricultural land ---3.91 (million ha)

- $\quad$ Rivers --19976 km

- Indigenous crop germplasm--3000 nos

- $\quad$ Orchids --900 (175 endangered spp.)

- Medicinal plants --119 Species belonging to 09 genera

- Aromatic plants --05 genera

- Livestock population --22.62 million

- Poultry --28.32 million

- Fish germplasms including ornamental-- 247 fish species

- Diverse Agro-climatic conditions

- $\quad$ Alpine Zone (>3500 m)

- $\quad$ Temperate Sub-Alpine (1500-3500 m) 
- $\quad$ Sub- tropical Hill Zone (1000-1500 m)

- $\quad$ Sub -Tropical Plain Zone: (800-1000 m)

- $\quad$ Mild Tropical Hill Zone: (200-800 m)

- $\quad$ Mild Tropical Plain Zone: (0-200 m)

- The quality rice (joharice of Assam, purple rice of Manipur etc.), fruits (Pine apple of Tripura, passion fruit of Nagaland and Mizoram, etc.) and spices (Ginger, turmeric, cardamom, king chili etc.) of the region has good national and international demand.

Besides, the region is biodiversity hotspot of a number of horticultural crop species, including citrus (17), banana (16), mango (2), peach (3), underutilized fruits (300), Prunus species, taro (300), yams (200), leafy vegetables, beans, cucurbits, lesser known vegetables and other ornamentals like Bauhinia, Cassia, Callistemon, Erythrina, Jacaranda, Rhododendron, Azalea, Bougainvillea, Camelia, Gardenia, Hibiscus, Jatropha, Nerium, Thunbergia, palms, foliages, bulbous plants and wild flowers.

\section{Land Resources}

The north-eastern ranges, the spurs of great Himalayas has two major sections- the Mishmi hills of Arunachal Pradesh and Patkai ranges run to the east and south of Assam along the Indo-Burma border. They are popular under different names in different parts of Assam (KarbiAnglong and North Cachar districts), Arunachal Pradesh, Nagaland, Manipur, Mizoram and Tripura and are collectively called Purvachal (Purva, east and Anchal, mountain). It comprises of low hills, plateaus and even plains. The Mishmi hills cover the lofty ranges of NEH with many summits rising above 5000 $\mathrm{m}$ and also many peaks of the Patkairanges rise between 2000 and $3000 \mathrm{~m}$. The Meghalaya plateau is really an eastward extension of the massive block of peninsular India to the east of the great gap of Achaean terrain. The central plateau of Khasi and Jaintia hills cover about 5000 sq. km area, and its outer limit is defined roughly by a $1500 \mathrm{~m}$ contour line. Among the 7 hill states of the northeast, Arunachal Pradesh has the maximum geographical area and least in Sikkim. However, both have the all types of climatic zones in this region.

Morphologically north eastern hills are marked by the development of a series of ridges and valleys, terraces, scraps, several geomorphologic or planar surfaces at different elevations (15 to $5000 \mathrm{~m}$ and above) etc. Only permanent snow cover exists around 28 and 7 per cent of the total geographical area of Sikkim and Arunachal Pradesh, respectively. Rivers pouring water from the adjoining hill states primarily constitute Brahmaputra drainage basin. The Himalayan (Sikkim and Arunachal Pradesh) rivers originate from the snow-clad mountains while from other states originate from the alive hills. It is very difficult to generalize the direction of the rivers. However, the rivers of Arunachal Pradesh and Sikkim are usually flowing from the north to south.

\section{Soil Resources}

The steep slopes, high relative relief feature and higher density of drainage of the mountain and hill areas stimulate soil erosion risks with a higher degree of sediment loss and also decrease the fertility of the soil of the landscape.

The soils of these hilly states were classified into 5 orders, 22 great groups and 45 subgroups and distribution of soil orders in different state are given in Table1. Thus the soils of this region are quite variable depending on the variability 
of climate, physiographic, parent materials and native vegetation. Mass movement of soil in the form of slips, glides, and mudflows and solution forms is common in this region due to high rainfall, jhuming on sloppy lands, deforestation, faulty methods of cultivation and road construction.

Table 1: Major Soil Types of North Eastern Hill Region

\begin{tabular}{|l|c|c|c|c|c|c|c|}
\hline Soil Order & \multicolumn{7}{|c|}{ State (Percent of Geographical Area) } \\
\hline & Meghalaya & Manipur & Sikkim & Tripura & Nagaland & Mizoram & A.P. \\
\hline Alfisols & 3.6 & 0.2 & -- & 5.0 & 4.8 & 2.6 & 0.3 \\
\hline Entisols & 10.7 & 23.1 & 43.0 & 8.0 & 4.0 & 21.5 & 35.6 \\
\hline Inseptisols & 45.7 & 38.4 & 33.4 & 80.0 & 76.0 & 37.3 & 37.3 \\
\hline Mollisols & -- & -- & 23.6 & -- & -- & 38.6 & -- \\
\hline Ultisols & 40.0 & 36.4 & -- & 7.0 & 17.2 & -- & 14.2 \\
\hline Misc. land & -- & 1.9 & -- & -- & -- & -- & 12.6 \\
\hline
\end{tabular}

Source: Velayutham and Bhattacharya (2000)

The soils are formed in situ excepting at foothills and near the rivers and streams, which are colluvial and alluvial in origin. The soils are rich in organic carbon with a decreasing trend as the depth of soil increased. Soils in the valleys and thick forest are fairly rich in organic matter and well drained. Most of these acidic soils contains high amount of exchangeable $\mathrm{Al}^{3+}$ throughout the soil column with almost increasing trend, indicating that they are still having preserved some weather able minerals which liberate $\mathrm{Al}$ ions from the edges of clay mineral through weathering processes. The soils developed on Bomdila group of rock are rich in clay content as compared to others. The major soil problems of the region are soil degradation, soil acidity and soil erosion due to shifting cultivation. Soil acidity is one of the most important factors affecting the productivity of crops and NEH soils occupies $54 \%$ of the total country acidic soils having a pH below 5.5 in this region.

\section{Mineral Resources}

Due to the wide diversity in composition and character of the terrain, the distribution of minerals in north-eastern soil across the seven states is not uniform. Many parts of Tuensanj and Mokkochung districts have vast petroleum reserves. Lower Assam has an area called 'Barail' which has a thick bed of sandstone and a mediocre band of shale with 2- meterthick coal seams. The eastern regions of Shillong, eastern parts of Khasi Hills and parts of Jaintia Hills of Meghalaya are rich in quartz. Compel, Ngopa, Serchhip, Khazwal and other parts of Mizoram have rich reserves of rare minerals. Shillong has rich reserves of Granite Rocks and most of these rocks have magnetic properties. Eastern Garo Hills of Meghalaya and West Khasi Hills have iron ore deposits in addition to iron floats. Manipu has rich resources of platinum and thorium including lead uranium. West Sikkim has adequate reserves of copper and traces of gold. Glass sand and quartz are found in sizeable quantity in Nagaon, Jiyajuri and Chapanala areas of Assam. Meghalaya is widely popular to be the most mineral rich states with unique deposits of kaolin, cement, phosphates, dolomite, carborundrum and uranium.

\section{Industrial Resources}

Out of the natural resource based Agri -industries, tea occupies a prominent position in Assam. The plants of tea grow in abundance in the valley of upper Brahmaputra. Assam is the major producer of tea in India and as of 2000 , the state has more than 1020 tea gardens with average production of $1769 \mathrm{~kg} / \mathrm{ha}$. In Assam, tea grows abundantly in Barak and Brahmaputra plains along with Snipur, Tinsukia, Golaghat, Dibrugarh, Jorhat and Sibsagar. At present, Assam produces $55 \%$ of total tea produced in India and about $1 / 6^{\text {th }}$ of tea produced in the world. Tea as a resource in Assam has alone earned more than 600 crores in foreign exchange and more than 1700 crores in domestic currency. 
Temi tea gardens in Sikkim produce fine variety of Oolong and Green tea that is mostly exported to foreign countries. This quality tea from Sikkim in NE India has impressed tea connoisseurs from across the world. It was established in 1965 and this is also one of the oldest tea gardens in India. Temi tea is widely acknowledged for its fragrance and class.

The entire region of North East India has great potential in terms of oil production and is kept for Hydro-carbon vision. The government has decided to invest 13 lakh crore in the coming 15 years in NE India. New technologies which will assist and help oil production will be brought in with the help of Government. As of now, natural gas production stands at 456 MT in the year 2015 while Natural Gas production volume stands at 113 MMSCMD.

\section{Forest Resources}

The region is rich in orchids, ferns, oaks (Quercusspp.), bamboos, rhododendrons (Rhododendron spp.), magnolias (Magnolia spp.), foliage plants etc. The region is rich in medicinal plants and many other rare and endangered taxa

The following figures highlight the biodiversity significance of the region:

- $\quad 51$ Forest types are found in the region broadly classified into six major forest types viz., tropical moist deciduous forests, tropical semi evergreen forests, tropical wet evergreen forests, subtropical forests, temperate forests and alpine forests

- Out of the 9 important vegetation types of India, 6 are found in the North Eastern region.

- $\quad$ These forests harbour 80,00 out of 15,000 species of flowering plants.

These include

- 40 out of 54 species of gymnosperms

- 500 out of 1012 species of Pteridophytes

- 825 out of 1145 species of orchids

- 80 out of 90 species of rhododendrons

- 60 out of 110 species of bamboo

- 25 out of 56 species of canes

In terms of floral species richness the highest diversity is reported from the states of Arunachal Pradesh and Sikkim amongst the North Eastern States as shown in the following table

\section{State Species Richness (Flowering Plants)}

Arunachal Pradesh 5000

Sikkim \pm 4500

Meghalaya \pm 3500

Assam \pm 3010 


$$
\begin{aligned}
& \text { Manipur } \pm 2500 \\
& \text { Nagaland } \pm 2250 \\
& \text { Mizoram } \pm 2200 \\
& \text { Tripura } \pm 1600
\end{aligned}
$$

These species belong to about 200 plant families out of 315 recorded from North East India. Some of the families such as Nepanthaceae, Illiciaceae and Clethraceae are unique in the world. These families are reported from the South East Asian countries and are represented by a limited number of species like Clethra sp. and Nepenthuskhasianain North East India. Siroy Lily (Liliummackliniae), a ground lily that produces beautiful flowers, is a narrow endemic found in the eastern border area of Manipur.

There are very interesting areas in the region that are termed as 'Isolation Belts' that have led to the isolation of certain species. Meconopsisbella, Cathcartialyrata, Seneciochola, Sausrealaneana, Geranium spp., Primulaelwesiana, P. Wattii and Swertiaburkillianaserve such examples in the Sikkim Himalaya

Orchids, believed to have evolved in this region, form a very noticeable feature of the vegetation here. Of about 1331 species of orchids, belonging to 186 genera reported from India, Northeast India sustains the highest concentration with about 900 species (Table 2). As many as 34 species of orchids from Northeast India are listed among the threatened plants of India. Out of the eight orchid habitat regions in India, the two most important areas namely, the Eastern Himalayas and the North eastern Region fall within the political boundaries of NER. More than 1/5th of the orchid species found in the region are endemic i.e. they are unique to the region and are not found anywhere in the world.

Epiphytic orchids are common in North- eastern India which grow up to an elevation of 2000m from sea level. Indian orchid species with high ornamental values originated from this region are Aeridesmultiflorum, Aeridesodoratum, Arundinagraminifolia, Arachnis, Bulbophyllum, Calanthemasuca, Coelogyneelata, Coelogyneflavida, C. corymbosa; Cymbidium aloifolium, C. lowianum, C. devonianum, C. hookerianum, C. lancifolium, Dendrobiumaphyllum, D. nobile, D. chrysanthum, D. farmeri, D. ruckeri, D. densiflorum, D. moschatum, D. fimbriatum, D. jenkinsii, Paphiopedilumvenustum, P. spicerianum, P. hirsutissimum, P. insigne, Phaiuswallichii, Pleione praecox, Renantheraimschootiana, Rhyncostylisretusa, Thunia alba, Vanda cristata, Vanda coeruleaand Vanda coerulescens (Singh, 1990).

Orchids are distributed from tropical to alpine zones in forest trees, secondary vegetations, river banks, bamboo and palm thickets, forest floor, grassy slopes and rocky areas and are considered as an element in Farming System Research (Chowdhery, 2001). The North East India has highest flora of monotypic orchid genera (Tandon et al., 2007). North East India is reported to harbor a large number of valuable threatened orchids also It is to be noted that there are some orchid species which are endemic not only to this region, but also to the home states in which they are distributed like in Sikkim and Arunachal Pradesh Himalayas, the Naga and Manipur hills, the Lusai - Mizo hills and Khasi -Jaintia hills (Nayar, 1996).

These are

- Dendrobiumspatella, Dendrobiumparciflorumand Luisiamacrotisfrom Assam

- Vanda coeruleaand Dendrobiumpalpebraefrom Arunachal Pradesh 
- Renantheraimschootianaand Cymbidium tigrinumfrom Nagaland

- Anoectochiluscrispus, Cymbidium eburneum, Habenariakhasiana, Liparisdeliculata, Paphipedilumvenustum, Taeniophyllumkhasianum and Tainiakhasianafrom Meghalaya

- Dendrobiumpalpebraefrom Mizoram

- Ascocentrumampullaceum var. auranticum, Epidendrumradicansand Vanda

- $\quad$ stangeanafrom Manipur

- Renantheraimschootianafrom Tripura

- Calanthewhiteana, Cymbidium whiteaeand Vanda pumilafrom Sikkim (Nayar, 1996)

Table 2: Orchid Distribution under Forest Cover in North East

\begin{tabular}{|c|c|c|c|c|c|}
\hline \multirow[t]{2}{*}{ State } & Area & Dense Forest & \multirow[t]{2}{*}{ \% Forest Cover } & \multicolumn{2}{|c|}{ Orchid } \\
\hline & \multicolumn{2}{|c|}{$000 \mathrm{~km}^{2}$} & & Genera & Species \\
\hline Arunachal Pradesh & 83,743 & 54,542 & 65.13 & 130 & 600 \\
\hline Assam & 78,438 & 15,842 & 20.19 & 74 & 182 \\
\hline Manipur & 22,327 & 5,309 & 23.77 & 67 & 207 \\
\hline Meghalaya & 22,429 & 3,305 & 14.73 & 98 & 352 \\
\hline Mizoram & 21,081 & 4,279 & 20.29 & 74 & 249 \\
\hline Nagaland & 16,579 & 3,531 & 21.29 & 64 & 241 \\
\hline Sikkim & 7,096 & 2,403 & 38.86 & 132 & 540 \\
\hline Tripura & 10,488 & 1,825 & 17.40 & 37 & 66 \\
\hline
\end{tabular}

Source: Chowdhery, H.J. (2009)

\section{Plant Genetic Resources}

The North-eastern India is one of the hotspot of mega biodiversity centre of the world which falls in between Eastern Himalayan belt and Indo-Burmese Region. The region is rich both in terms of primary and secondary crop diversities.

\section{Cereal}

It constitutes the major group that contributes the staple food. Rice, maize and barley are the common cereals crops, while the wheat cultivation is very limited in the north eastern region. About 9650 landraces of rice (Oryzasativa) occurring in the region which grows in different ecological situation. At least 7 taxa of wild relatives of rice (Oryza) grow in this region which includes Oryzarufipogon, O. glomerata, O. meyeriana, O. officinalis; Leersiahexandra; Zizanialatifolia, Hygrorhizaaristata. Wonder rice of Nagaland is a subject of future research.

\section{Maize}

(Zea mays) is the second dominant crop in entire hill region. Lots of variability exists among the genotype in terms of Cob and grain morphology. Based on the origin, evolution, migration and introgression, Singh (1975) has identified 15 distinct races and 3 subraces. Sikkimprimitive, one of the interesting land races which produce 4-6 cobs in a plant, found in the region. Nagaland and Mizoram is the major producer of the crop among the hill states. The intergeneric hybridisation is also found in this crop and the related taxa like Coixlacryma-jobi, Euchlaenamexicana and Tripsacumdactyloidesare found in very limited cultivation. 


\section{Barley}

(Hordeumvulgare) grows in high altitude of Sikkim and Arunachal Pradesh, where Rice cannot be grown, while wheat (Triticumaestivum) is an introduced crop in the region. This crop is confined within very limited area of Assam State.

\section{Pseudo Cereals}

This group of crop includes buckwheat (Fagopyrumesculentum), amaranth (Amaranthhypochondriacus); chenopods (Chenopodium album), jobs tear (Coixlacryma-jobi), millets like finger millet (Eleusinecoracana), foxtail millet (Setariaitalica); pearl millet (Penisetumtyphoides); jowar (Sorghum biceor) and their related species. Such crops are normally grows in high altitudinal area where the other cereal crops are not suitable. Moreover, such crops serve the alternative need of nutritive value and other requirement of local people and not for commercial purpose.

\section{Grain Legumes}

Crops belong to this group meet up the requirement of pulse and vegetable purpose. A few legumes are utilised for their tubers and not for grain purpose. Rice bean (Vignaumbellata) is the major pulse crop of the hills. Black gram (Vignamungo) is grown in large scale only in Sikkim state in the region. Pigeon pea, lentil, lathyrus are commonly grown in Assam. Soybean, cowpea, pea, french bean, sem (Dolichos), jack bean, tree bean (Parkiaroxburghii) are grown as vegetable. Considerable diversities are available within these crops. Tubers of Moghaniavestita, Eriosemachinense and Pachyrrhizuserosus are eaten as raw by the tribal's

\section{Oilseeds}

The utilization of oil is very scanty among the hill people and perhaps due to the less cultivation of oilseeds. Among oilseeds, mustard (Brassica spp.) is only cultivated in Assam plains, otherwise leafy brassical cultivation is dominant for leaves. Bhanjira (Perillafrutescens) is commonly used for Chutney purpose. Systematic cultivation of this crop is lacking. Adoption of crop cultivation is depended on the food habit of the tribal community. Therefore sesame cultivation is confined in Karbi Anglong district of Assam, where considerable amount of sesame diversity does occur. Otherwise rest oilseed crops like Niger, groundnut, castor and linseed cultivation are scanty and limited.

\section{Vegetables}

This group of crop diversities includes mainly the members of Cucurbitaceae and Solanaceae. At least 17 species of cucurbits and 12 species of Solanum are consumed by the local people many promising wild relatives can also contribute as donor member in hybridisation program. Cucumishystrix, Gymnopetalumcochinchinensis, Luffaaegyptica, Hodgsoniamacrocarpa and Trichosanthescordata is the novelties of the region. Enormous diversities exist within the genera like Cucurbita, Momordica, Lagenaria, Benincasa, Luffa, Cucumi, Sechium, Solanum, Abelmoschus and Capsicum in their infra specific levels as well asin their landraces.

\section{Tuber Crops}

This group mainly constitutes the taros, elephant foot yams and yams. A large number of variability's are available in Colocasia and Dioscorea. Tribes of the region are largely dependent on these crops for their livelihood which also help them in their integrated farming system. In Colocasia, most variability is recorded in KallaKachu, Ban kachu, Ahu-kachu, Dukhkachu, Mukhi, Panchmukhi, Man kachu and Jalkachu. 
In Dioscoreaa bout 28 species and 25 varieties has been reported from NE region mainlyin the Garo hills (Sharma and Hore, 1995). The major species found in the region are D. alata, D. esculenta, D. bulbifera, D. pentaphylla, D. hamiltonii, D. cylindrical, D. sativa, D.oppositifolia and D. deltoidea and D. floribunda. Dioscorea is the crop which is mainly grown by tribal farmers in their jhum field. In sweet potato, mainly two types are available in the region i.e. red and white. In tapioca, both sweet types and bitter are only available. Tapioca and sweet potato have been introduced long back in this region and they are well acclimatized.

\section{Spices}

There are several cultivated types of ginger available in the region, which are generally named after the localities they are being grown. Certain indigenous types namely Maran, Bhola and Jorhat Local of Assam have been reported to be equally good in rhizome yield as well as in size. The pungency in ginger is due to gingerol, which is found highest in Meghalaya Local genotype and very suitable for export purposes. In Mizoram, local types Thingpui, Thingaria and Thinglaidum are grown at large scale. Black ginger having rhizomes with bluish black tinge inside is reported to have medicinal properties and is grown by the inhabitants of Mizoram for commercial as well as their own use. In Sikkim, local types Bhainse and Goruba than are grown commercially due to their high yield potential and big size rhizomes. In Meghalaya, in addition to local types namely Meghalaya Local and Tura Local, considerable area has been brought under selected type Nadia. Certain indigenous types of turmeric namely Manipur Local, Nagaland Local, Sikkim Local and Jorhat Local of Assam have been reported tobe equally good in rhizome yield. Dry matter recovery of these varieties has been found to be even equal or better than certain improved types. In Meghalaya, Lakadong is the main variety and more than 50per cent area is under this variety.

\section{Fruits}

The major native fruits of North-eastern Hill region are citrus, banana, jackfruit, mango, rosaceous crops and minor fruits. Among introduced crops pineapple, passion fruit, papaya and kiwi fruit are well acclimatized and naturalized. Many wild relatives of various fruit crops are also available in the region. The extents of diversities in such crops are as follows:-

- Citrus - 17 species with their 52 varieties together with many intermediates.

- Banana - It constitutes both suckering (Musa) and non -suckering (Ensete) group together with ornamental types (Rhodochlamys). All these together forms 16 species. Musa esculenta (A genome) and M. Balbisiana (Bgenome) has contributed many cultivars in the region.

- Jackfruit - Artocarpusheterophyllusis the only cultivated species. Three wild species (i.e. A. lakoocha, A. chamaand A. hirsuta) are also edible.

- Mango- Six cultivars, two wild species i.e Mangiferasylvatica and M. Khasiana do exist in the region. Manipuri dwarf mango cultivars are novelty of the region.

- Rosaceous- These includes Pyrus (2 species); Prunus (6 species); Malus (1fruits species species); Sorbus (2 species); Rubus (9 species) ; Docynia (2species); Duchesnia (1 species) and Fragaria (2 species)

Relatively less important crops include the members of Syzygium, Aegle, Psidium, Annona, Averrrhoa, Punica, Vitis, Litchi, and Zizyphus. A few dozen of economically important minor fruits which could be cultivation (De, 2017) this 
can help the farmers to earn cash in their odd times. The potential species of this category includes the species of Elaegnus, Myrica, Baccaurea, Castanopsis, Vibernum, Gynocardia, Calamus, Elaecarpus, Dillenia, Cornus, Emblica, Feronia, Flacourtia, Garcinia, Morus, Spondius, and Rhusetc.

\section{Medicinal and Aromatic Plants}

There are about 2500 plant species in India are utilized for medicinal purpose against different ailments. The major consumption is mostly within the ethnic people who have no scope to afford and reach to modern medicine. Northeastern region provides a varied eco-climate and perhaps due to this, a large number plant species and their diversities exist. Altitude wise the region can be classified in to four (4) zones i.e. Tropical, Sub-tropical. Temperate and Alpine, which are the habitats for occurrence and suitable for ex-situ cultivation practice (Table 3).

Table 3: Medicinal and Aromatic Plants of North East Region

\begin{tabular}{|c|c|c|}
\hline Climatic Zone & Altitude & Species \\
\hline Tropical & $50-500 m$ & $\begin{array}{l}\text { Plantagoerosa, Adhatodavesica, Andrographispaniculata, Withaniasomnifera, } \\
\text { Ocimum sanctum } \\
\text { Centellaasiatica, Vitextrifolia, Aquallariaagalocha } \\
\text { Tinosporacordifolia, Bacopamonieri, Pogostemancablin }\end{array}$ \\
\hline Subtropical & $500-2000 \mathrm{~m}$ & $\begin{array}{l}\text { Ophiorhizamungos, Artemisia maritima, Diachroafebrifuga, Hydnocarpuskurzii, } \\
\text { Hedyotisauriculata } \\
\text { Litseacubeba, Mucunapruriens, Swertiachirata } \\
\text { Rauvolfiaserpentine, Alpiniagalangal, Clerodendron } \\
\text { Colebrookianum, Plumbagozeylanica, Acoruscalamus } \\
\text { Paederiafoetida, Houttyniacordata, Potentillasundaica, Berginiaciliata, } \\
\text { Dactylorhizahatagirea } \\
\text { Acoruscalamus }\end{array}$ \\
\hline Temperate & $2000-3000 \mathrm{~m}$ & $\begin{array}{l}\text { Panaxpseudoginseng, Dicentrascandens, Coptisteeta } \\
\text { Aconitum heterophyllum, Picrorhizakurroa, Podophyllumhexandrum, } \\
\text { Taxuswallichiana, Nardostachysjatamansi, Berberisaristata, Valerianawallichi }\end{array}$ \\
\hline Alpine & $>3000 \mathrm{~m}$ & Rheum emodi, Tupistranutans, Saussureacostus \\
\hline
\end{tabular}

\section{Fishery Resources}

\section{Rivers}

The north-eastern region is blessed with as many as 58 notable rivers/tributaries besides numerous rivulets/hill streams; mighty Brahmaputra (the largest river of the region) and Barak along with their tributaries form more than half of these rivers (Bhattacharya, 2007).Major rivers of Arunachal Pradesh like Kameng, Dikrong, Ranganadi, Subansiri, Siang, Dibang, Lohit, Noadihing and Tirap are steep and turbulent, often passing through deep gorges. They along with tributaries flow for 2,000 km in the state. In Assam, the Brahmaputra River flows for730 km, receiving 47 important tributaries such as Dibang, Subansiri, Ranganadi, Jiabhoroli,Pagladiya, Beki, Manas, Saalbhanga and Sonkosh in the north bank and Lohit, Buhridihing, Disang, Dhansiri, Kopili, Kulsi and Jinjiram in the south. The Barak River drains the southern Assam districts of Cachar, Karimganj, Hailakandi and North Cachar Hills. The combined length of all rivers and their tributaries in Assam is 4,820 km. Manipur has two major rivers viz., Barakand Imphal. The Barak River with its tributaries like Irang, Leimatak, Nakaror, Makru and Tuivai mainly dissects the hills while the Imphal River drains the valley districts. Iril, Thoubal, Chakpi and Khuga rivers directly join Manipur River whereas Namol, Nambul and several rivulets draining the eastern slopes of Tameng long hills are connected to the river through the Loktak Lake. Estimated length of rivers in Manipur is 2,000 km. Meghalaya's 5,600 km of rivers mainly comprise the north-flowing ones like Umiam, Digaru, Dudhnoi, Krishnai and Jinjiram (all southern tributaries of R. Brahmaputra). The main south-flowing rivers of the state are 
Balat, Kynchiang and Simsang. There are 21 rivers in Mizoram, of which Tuirial, Mat, Tlawng, Karnafuli and Tairei are the important ones. The serivers along with tributaries, streams and creeks run for $1,700 \mathrm{~km}$ forming an important fisheries resource of this hilly state. Jhanji, Dikhow, Diphu, Daiyung, Dhansiri (all tributaries of R. Brahmaputra), Barak and Tizu are the main rivers of Nagaland, which have a combined length of 1,600 km. Sikkim has two major rivers, Teesta and Rangeet, with a total length of $900 \mathrm{~km}$. The serivers originate from the glaciers of north and west Sikkim. Important rivers of Tripura are Longai, Juri, Deo, Manu, Dhalai, (all in north Tripura), Khowai, Howrah (West Tripura), Gumti, Mahuri and Feni (South Tripura). These rivers - along with other small streams and rivulets -have a total length of 1,200 km. Thus, the combined length of all types of rivers in the Northeast is $21,180 \mathrm{~km}$. Along with their tributaries, these rivers harbour a diverse and rich fish fauna.

\section{Floodplain Wetlands (Beels), Lakes and Swamps}

Floodplain wetlands (oxbow lakes, tectonic depressions and other wetland formations on the floodplains of rivers) and associated swamps constitute an important fisheries resource of the north-eastern region, especially in the states of Assam and Manipur (Bhattacharya, 2007). The region also has a number of upland lakes, the most important ones being Loktak Lake (Manipur) and Psango Lake (Sikkim), respectively. Assam has the largest area (100,815 ha) under floodplain wetlands (locally called beels) in the country. However, a number of these beels have been converted to swamps as a result of continuous siltation and macrophyte infestation. The Imphal valley of Manipur has 21,000 ha of pats (as the floodplain wetlands are known in the state), which along with the Loktak Lake (19,150 ha), make it the second most potential state in the region for fisheries development. Arunachal Pradesh Meghalaya, Tripura, and Nagaland have 2500 ha, 375 ha, 500 ha and 215 haof beels, respectively. The total area of beels, pats, lakes and swamps in the region is 144,555 ha. Floodplain wetlands harbour rich fish fauna especially because these open water bodies' present the conditions of both flowing and stagnant waters and therefore houses fish species present in both these habitats.

\section{Ponds and 'Mini Barrages'}

Assam (31,232 ha water spread area) has the largest area of ponds among the north-eastern states. Tripura has 13,342 ha aquaculture ponds, of which 4,270 ha are improvised impoundments created by blocking the streams. Locally called mini-barrages, this type of ponds are also popular in Mizoram where there is a dearth of plain land for digging ponds (Sugunan, 2003). Mizoram has 1,800 ha of ponds while Manipur, Meghalaya and Nagaland have5, 000 ha, 500 ha and 500 ha of ponds, respectively. Arunachal Pradesh has 250 ha of ponds, some of which are suitable for coldwater fish culture. It is estimated that out of the 66,795 ha of potential pond area available in the region 52,119 ha are already available for aquaculture. The natural ponds still houses a considerable number of fish genetic resources even though natural fishes present in aquaculture ponds are by and large eliminated to give way to a few cultivable fish species (numbering 12 at present).

\section{Reservoirs}

Although the north-east has enormous potential for creating impoundments for generating hydroelectric power, only a few projects covering 17,435 ha water spread area have come up. They include Umrang and Khandong reservoirs created under the Kopili Hydroelectric Project in North Cachar Hills district of Assam (1,713 ha), Umiam, Kyrdemkulai and Nongmahir reservoirs in Meghalaya (8,430 ha), Gumti reservoir in Tripura (4,500 ha), Khopum dam of Manipur (100 ha) and the Palak lake of Mizoram (32 ha). In addition, Daiyangreservoir in Nagaland and Ranganadi reservoir in 
Arunachal Pradesh have recently being commissioned. A number of reservoirs are in the pipeline including the ones presently being constructed by NEEPCO, Shillong on Tenga and Bishom rivers (tributaries of R. Kameng/Jiabhorali) in Arunachal Pradesh and the one on River Pagladiya in Lower Assam (by NHPC, New Delhi). It is estimated that the Brahmaputra and Barak river basins together constitute 50\% of the total hydel power potential of the country (Sinha, 1990). Reservoirs also harbour rich fish fauna since (i) they create huge areas of comparatively stable environment, which is a continuum of the river, and (ii) they have both flowing and stagnant waters at the same time and therefore houses fish species present in both these habitats. Unfortunately, the exotic common carp has established itself in Umiam reservoir of Meghalaya (Bhattacharya, 2005) at the cost of native fish species

\section{Low-Lying Paddy Fields}

The North-east has 42,280 ha of low-lying areas of which only 2,670ha is reportedly developed for undertaking paddy-cum fish culture in them (Bhattacharya, 2005). At present, paddy-cum fish culture is practised in some appreciable extent only in Nagaland and the Apatani plateau of Arunachal Pradesh. There are some traditional practices of growing fish in the paddy fields in certain other areas like Juria block of Nagaon district (Assam) and the hill tracts of Ukhrul district (Manipur). But these culture practices are low yielding and mostly subsistence in nature. Natural low-lying areas of the region house a rich variety of fishes.

\section{Ichthyo - Faunistic Resources}

Sen (2000) reported 267 indigenous fish species belonging to 114 genera under 38families and 10 orders occurring in the North-east. Two endemicmurrel species viz., Channableheri and C. aurantimaculata reported from the region.

Among the states Assam has the largest number of ichthyospecies numbering 216(Bhattacharya et al., 2003), followed by Arunachal Pradesh (167), Meghalaya (165), Tripura (134), Manipur (121), Nagaland (68) and Mizoram (48 species) (Sen, 2000). These include 31species endemic to the region. The most important commercial fishes of Sikkim are the snowtrout (Schizothoraxspp.), mahaseer (Tor putitora), cat fishes (Glyptothoraxspp, Bagariusspp, Pseudechenciessp) and a number of Cyprinids (e.g., Garraspp., Bariliusspp, etc)

Prominent endemic species of the region include Channableheri, C. stewartii, C. aurantimaculata, Lepidocephalusgoalparensis, Nangraassamensis, Bariliusshacra, B. tileo, Contaconta, Crossocheiluslatius, Danioaequipinnatus, D. naganensis, Garramanipurensis, G. naganensis, Puntiusshalynius, Tor progeneius, Mystusmenodamenoda, Colisalabiosus, Glyptothoraxcavia, Aborichthysgaroensis, Noemacheilusarunachalensis, Schisturamanipurensis, Amblycepsapangi and Psilorhynchushomaloptera.

\section{Cropping Systems}

Rice, maize and potato are the staple food crops of this region and rice based cropping system is common with the exception of Sikkim, where maize based cropping system is prevalent. But the yield is very poor. The most efficient cropping systems identified for different area in the region are potato-rice, rice-rice, maize-ragi, maize-mustard, maizesunflower, maize + French bean-mustard. The groundnut has proved potential and can be a good substitute of uneconomical upland rice and maize or it can be grown as intercrop with rice and maize for higher productivity and return (Panwaret al., 2003).Mundaet al., (1999) reported that maize (green cob)-groundnut-mustard was the most profitable cropping system in mid altitude of Meghalaya followed by French bean (Green pod) -French bean (Grain). 


\section{Indigenous Farming System of North Eastern India}

\section{Shifting Cultivation}

Shifting cultivation is prevalent in Nagaland, Manipur and Mizoram. The productivity of jhum land is very low ( $0.87 \mathrm{t} / \mathrm{ha})$ especially where the jhum cycle is shorter (2-3 years). For higher productivity of jhum, improved practices like proper soil and water conservation measures, improved agro-techniques viz., improved variety; proper land use systems through integrated farming system and agro forestry intervention technologies, planting across the slope etc. and models of watershed based farming systems can be adopted.

\section{Bun System of Cultivation}

This system of cultivation is practiced mainly in the state of Meghalaya. Under this system, the crops are grown on a series of raised beds locally referred to as "Bun" formed along the slope of the hills. Presently, most of the farmers grow crops consecutively for two years in Bun field. In first year, generally tuber crops like ginger, turmeric, potato, sweet potato etc. and vegetables followed by upland paddy are grown.

\section{Rice-Fish System of Apatani Plateau}

It is a multi-purpose water management system, which integrates land, water and farming system by protecting soil erosion, conserving water for irrigation and paddy-cum-fish culture (Sarangi and De, 2005). It has been practiced in a flat land of about $30 \mathrm{~km}^{2}$ located at an altitude of about 1,525 meter msl. In the humid tropic climate of Lower Subansiri district of Arunachal Pradesh Local tribe "Apatani” which develop this system dominates the area. In Manipur and Nagaland Paddy-cum-fish culture is practiced in terraced fields where a small pond is dug in the middle or corner for harvesting of fish during the harvest of paddy. Two crops of fish and one crop of paddy is commonly harvested conserving water throughout the year. Technology intervention of Common Carp found most suitable in the higher altitudes grown with improved rice varieties. In the system, Grass carp is another competent fish commonly grown with rice as pre-kharif crop in the plain of Manipur.

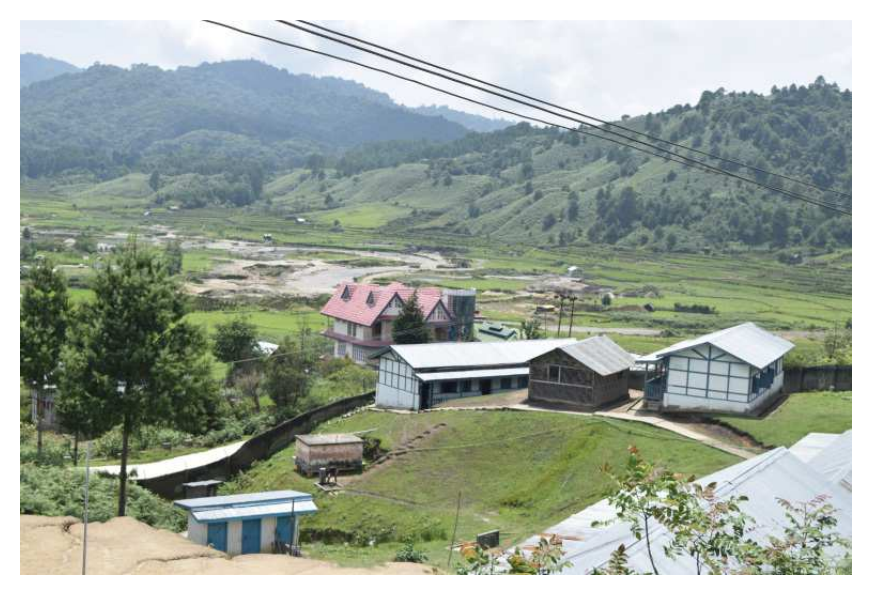

Figure 1: Rice-Cum Fish Culture in Apatani Area of Arunachal Pradesh

\section{Bamboo Drip Irrigation System}

The tribal farmers in Muktapur, Jaintia hills district of Meghalaya have developed the indigenous technique of bamboo drip irrigation. Betel vines planted with are canutas the supporting tree are irrigated with this system, in which 
water trickles or drips drop at the base of crop. In this system, water from the natural streams located at higher elevation is conveyed with the use of bamboo channels, supports to the site of plantation through gravity flow.

\section{Alder Based Agriculture in Nagaland}

In some pockets of Nagaland the farmers use Alnusnepalensis (Alder) tree for agriculture. In this system the Alder seedlings are planted on the sloppy land intended for cultivation and the alder grows fast till attain six to ten years old. At this stage initially the trees are pollarded, the leaves and twigs are burnt and ash is mixed with soil to prepare it for raising crops. Subsequently also pollarding is done once every four to six years. Under this process coppice are cut except five to six on top of the main trunk and crop schedule is followed including fallow period of two to four years. The bigger branches stripped of leaves are used for fire wood, while the root of the tree develop nodules (colonies of Frankia) responsible for fertility improvement whereas spreading nature of the roots helps in preventing soil erosion in slopes.

\section{ZABO System}

"Zabo" is an indigenous farming system of Nagaland. The word "Zabo" means impounding of water it has a combination of forest, agriculture and animal husbandry with well founded soil and water conservation base. It has protected forest land towards the top of hill, water harvesting tanks in the middle and cattle yard and paddy fields for storage for the crops as well as for irrigation during the crop period. Special techniques for seepage control in the paddy plots are followed. Paddy husk is used on shoulder bunds and puddling is done thoroughly.

\section{REFERENCES}

1. Bhattacharya BK. 2005. Floodplain wetlands of Assam: Management options and issues from the fisheries perspective. In Choudhury MC, Shrivastava NP, Manna RK (eds.), Participatory Approach to Management of Inland Fisheries Resources of North eastern India. Bull. No. 135, CIFRI, Barrack pore, India, 79-87

2. Bhattacharya BK. 2007. Fisheries resources of north eastern India: Potentials and constraints for development. In Das A, Kumaresan A, Bardoloi R K, Bujorbaruah, KM, Naskar S. (eds.), Complementary role of livestock and fisheries towards sustainable farming in north east India. ICAR Res. Complex for NEH Region, Umiam, Meghalaya, 187-201.

3. Bhattacharjya BK, Choudhury M, Sugunan VV. 2003. Ichthyofaunistic resources of Assam with a note on their sustainable utilization, In Mahanta, P. C. and Tyagi, L. K.(eds.), Participatory Approach for Fish Biodiversity Conservation in North East India, Workshop Proc. NBFGR, Lucknow, India.1-14.

4. Chowdhery HJ.2001. Orchid diversity in north-east India, J. Orchid. Soc. India15, 1-17.

5. Chowdhery HJ. 2009. Orchid diversity in north eastern states of India. J. Orchid. Soc. India, 23, 19-42.

6. De LC. 2017. Valuable indigenous fruit crops of North-eastern Region of India. International Journal of Research in Applied, Natural and Social Sciences5, 21-42.

7. Munda GC, Hazarika UK, Saxena DC, Singh Raj, Patel DP. 1999. Performance of cropping systems under mid altitude rainfed dry terraces of Meghalaya. Indian Journal of Hill Farming12, 106-110.

8. Nayar MP. 1996. Hotspots of endemic plants of India, Nepal and Bhutan. Tropical Botanic Garden and Research Institute, Trivandrum, India.

9. Panwar AS, Singh NP, Saxena DC, Munda GC. 2003. Agricultural status and cropping systems in NEH region, In: Proc. Approaches for increasing agricultural productivity in hill and mountain ecosystem (Eds. Bhatt BP, Bujarbaruah KM, Sharma YP, Patiram. pp. 191-195. ICAR Research Complex for NEH Region, Umiam, Meghalaya. 
10. Sarangi SK, De LC. 2005. Indigenous rice cultivation practices of Arunachal Pradesh. Indian Journal of Hill Farming18, 54 64.

11. Sen N. 2000. Occurrence, distribution and status of diversified fish fauna of north east India, pp31-48.In: Sinha M, 1994. Fish genetic resources of the North-eastern region of Indian J.

12. Inland Fish. Soc. India26, 1-19.

13. Sharma BD, Hore DK. 1995. Genetic Resources of Yams in NE India with special reference to Garo hills (Meghalaya). Indin Journal of Hill Farming8, 145-151.

14. Singh B. 1975. Races of Maize in India, ICAR, New Delhi.

15. Singh F. 1990. Indian orchids. Indian Horticulture35, 14-15.

16. Sinha M. 1990. Reservoir fisheries - its present status and future potentials in the north-eastern region, In: Jhingran AG, Unnithan VK (eds.), Reservoir fisheries in India. Proc. Nat. Workshop, 3-4 January, 1990. Asian Fisheries Society- Indian Branch, Mangalore, India, pp57-64.

17. Sugunan VV. 2003. Fishery resources potential of the north-eastern region. In: Mahanta P C, Tyagi, LK (eds.), and Participatory Approach for Fish Biodiversity Conservation in North East India. Workshop Proc., NBFGR, Lucknow, India, 21-32.

18. Tandon P, Abrol YP, Kumaria. 2007. In: Biodiversity and its significance, IK International Pvt Ltd., p 370.

19. Velayutham M, Bhattacharya T. 2000. Soil resource management, In: Natural Resource Management for Agriculture Production in India, (eds. Yadava, J.S.P. and Singh,G.B.) ,pp.1-135.Alfa Printers, New Delhi. 
